elusion as to the value of this substance ns a circulatòry stimulant. The drug is freely soluble in water, produees apparently no gastrointestinal irritation, and when given by the mouth is uncertain and slow in its effeet. When administercd in doses from 20 to $40 \mathrm{mg}$. it produees a marked and abrupt rise of pressure, whieh is very fugaeious, and is sometimes associated with slowing of the pulse rate and irregular heart aetion. The substance should be of value in the treatment of conditions in which there was marked vasomotor depression, but it apparently cannot be depended upon for any prolonged aetion.

I wish to express my thanks to Prof. W. E. Dixon and Dr. II. II. Dale for their assistance. Also to Dr. T. Mellor Tyson, Dr. Willinm E. Tuglies, Dr. L. N. Boston, and Dr. Ward Briuton for the privilege of selecting cases from their wards.

\title{
THE OCCURRENCE OF TRICHOMONAS HOMINIS IN GASTRIC CONTENTS WTTH A REPORT OF TWO CASES.
}

\author{
Br Fraik Surtuies, M.D.,

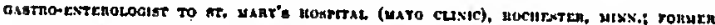

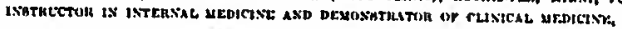

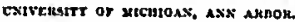

Slice the aetive Caueasian occupation of the Plilippine Islands, the West Indies, and Central America in the last deende, the study of protozoa parasitic to the gastro-intestinal tract of man has reeeived great impetus. New and valuable faets have been brought forward by Musgrave and Clegg,' Walker, and others concerning the biology of amebre and flagellate protozon, as well as the etiology and symptomatology' when sueh are present in the human intestinal canal. Following the pioneer work of Dock, 3 of reeent years, Freund and Sistrunk have shown that anebe and fingellate protozoa, which were formerly cousidered to be present but rarely in the feces of individuals who had never visited tropieal regions, are by no menus infrequent in the diselumrges of persons residing in the tempcrate zoule.

With inereasing amounts of material arailable for proper exannnation, it is somewhint eurious that the presence of amebre and flagellate protozoa (particularly trichomonas hominis) outside the intestines proper lias not bcen more frequently elironicled. A rather close scrutiny of available litcrature reveals the faet that

\footnotetext{
I Publications of the Government Iaborstotics, Mfanila, P. 1., 1904, 93; Philippine Jisur. of Sci. (Manila), 1900, I, 009; itsid., 1900, jit, 7 .

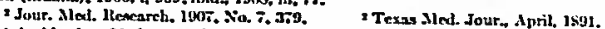

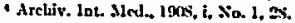

Jour. Amer. Mal. duste. 191 1, Ivii, 1507.
} 
within the last eight years there has been but one observation detailing the presence of flagellate protozon in the stomaeh, esophagus or orul eavity. In this eountry and abruad, it is quite likely that search for these parasites has not been male apart from intestinal discharges.

Nearly-fourteen y'ears ago Skaller ${ }^{6}$ reported 2 cases of eareinoma at the cardiae end of the stomiel where flngellates similar to "triehomonas vaginalis" (Donne, Doeks) were discovered in the gastric extracts as well as in the patient's stools. Shortly afterward Strube? recorded a sinilar case, a male patient, with foulsmelling vomitus and a "lanrd tumor" in the epigastrinm. A few vears later Colnhleim" deseribed the presenec of trielomonas lominis in a ense clinically diagnostienterl "gastritis," in the test-meal extract of which the total acidity was 19 and the free lydrochlorie acil was estimaterl at 12, aml in a second euse clinicully. "carcinoma ventrienli" atnebate were occisiomally present. Following Colnhleim, \%abel" reported 3 ceises where he hial demonstrated flagellate protozon in both gastric and intestinul contents. Two of his cases were dingnostieatel "acly-lia gastrica." These lad leptotlırix, amclie, spirillie, and trichomonas hominis in the romitus, gastrie washings, and the stools. The third ease was one of etreinoma of the stomach, at first with slight interferenee with motility, but later witl marked retention and the presence of lactie acid. Megastona entericum was demonstrated in the gastric extracts. Culnuheimin shortly after statel that he had seen eercomonas hominis and trichomonas looninis in cancerous involvements of the tongue and esophagus and also in the mouths of individuals with carious tecth. "This obscrvation was verifiel by von Leyden. ${ }^{3}$ So far as we have been able to discover, the most complete study of flagellates in gastric extraets has been made by Rosenfeld." Ie comments upon the faet that trieliomonas lominis has been reporterl usurally in extrnets that show ncliylia, but elaims that this does not necessarily follow inasnmeh is one of his eases had a free lydroelilorie estimation of 6 and a total acidity of 37 . Rosenfeld describes 6 instances of the presence of trichomonns hominis in gastrie contents, where careinomas involved various positions in the wall of that viseus. They were frequently aecompaniet by lung bacilli (Bous-Oppler) and leptotlurix. The number of flugellate protuzoia inerensed in proportion to the diminution of aeidity and as retention progresserl. All Rosenfeld's patients exhibited eachexia and palpable tumor in the epigastrium.

\footnotetext{
- nerl. klin. Woeh, June, 1595, 5 jil.

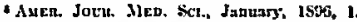

- Betl. thin. Wireli., 1s9s, No. 32, 70s.

16 Deutseh. ned. Wocls, 1001. No. XXY11.

"Ireh. I. Vertauuasokrank., 1901, vii, 500.

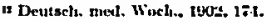

a Ibja., 1s:.

T Campt. renil. de. r.Iend. dis Se., IS36, iii, 355.
}

to lhid. 19,t, sxx. 17it. 
We lave not been able to discorer a report of the finding of triclomomas lomminis in gastrie extracts outsile of Continental literature. P(rlaips a routine searcli for this parasite las not bexn male in gastric contents. Olscervations upon its oecurrenee in the stools of patients living in the northem balf of the United States are rapidly- becoming more mumerons, as the recent study of Sistrunk ${ }^{13}$ demonstrates. It wonld sexin timely to place on record somewbat fully the following 2 eases where trichomonals were demonstrateel in gastrie extracts. Search for this and other parasites in gastrie contents may therelyy be stimulaterl.

I.

C.ISE: IRFIPITS.

Cass: I.-N/rs. G., agerl twenty-cight years, a uative of the mineral well district of 'lexis, mas referreyl ly- P'rofessor Aldred Seott Wartlin, Anu Arbor, Aliclit;an, Angnst 17,1905 .

Subjectirc Symploms. Screrc leadiaches, comning on paroxysmally, especially follawing cxertion, excitement, etc; attacks of "dyspepsin," maindy, nausea, beleluing of gras, with "sore stomacla;" obstimate constipation and general weakness.

Family Ilistory. Negative.

Personal Ilistory. Was a healtly chilh, raisel in soutlueru Texas; married at sixteen, a widow at nimetex"ll. Wis operated upon at that time for "ovarian tronble;" made a good recovery" und then commencel the stuly of uirsing at Dallas, Texas. Later, latd her appetelix and one ovary removel. She overworkel at the minses' training school and laal a "nervous breakilown" when ageyl twenty-fonr years. Wais again marrieyl a year later, ulthongls she was not well at the time, complaining of "sore stomach," dyspepsia, ond weikness. Slre was namseated constantly, but never vomitel. Ilahitual constipation resulted in lemorrhoids, which required several operations lefore she bectume comfortalble. it these operations slic lost much blood. The bemorrboids bled especially frecly again in tlue spring of 190S. Menstruation lias been generally regular; patient never pregnant, never passed clots nor bad leucorrbea. No uriuary symptoms.

The prescut tronble dates back about two years. The main symptoms lave been loss of appetite, nousea, distress af ter eating n liearty meal, belcling of gas, severe prostrating lecalaches, and weakmess. 'The headaclies are most frepuent and severe when the "(lyspepsia" is most troublesnme and when constipation is marked. 'The paticut lats lost ten porinds in weight dnring the last nine montlss. Constipation lass been relieved by raw fruit 
and fresh vegetable diet nul large driughlts of a 'Texas mincral well water, not boiled.

Examination. Temperature, 9S.S; pulse, 6S; respiration, 22 (3isis.).

Paticut of mediun build with modernte annount of paumieulus; skin pale, sallow throughiont, but not jumuliced; seleroties and uncous surfaces pale but not jaumulieed; tongue has a moderitely henw, grayish yellow; allierent coat; breath, heavy.

Month, nose, and tliroat, negative. Ileflexes, neghtive. Thorax, uenative.

Ablomen, slightly distenuled, navel above the level of the ribs. Slight tenderness in right iliac fossiz; both kidhey's easily palpable; liver and spleen negitive. llather markerl girnliug throughout cutire aludomen; splashing sounds on tupping between nivel und pubis. On iuflation, stomach holds $2 \mathrm{~s}$ bulbs without diseomfort; tle lesser eurviture listinetly scen at one finger's breattl above the unvel in, the miclline, while the greiter enriature is minde ont at four fingers' brealth leclow the navel in the median line.

- l'elvis, right orary and tube removel; left oviry free; nterus in good position and frec; pelvie floor molerutely stroug; external genitalia uegative (Dr. L'rank Witter).

Blood: lied blook eorjuseles, $4,0,00,060$; white blood corpuseles, 6210; hemoglohiu, 95 per. cent. Differentinl formula (350 white cells counted): Small lymphoeytes, 11.14 per cent.; large lymplioeytes, 4.0 per ecnt.; transitionals, 0.57 per ecut.; polymorplisoiniclears, 74.5 per eent.; cosinopline polymorphonuclears, $1 . \bar{T}$ per cent.; myeloeytes, $0.2 S$ per cent.; mast cells, $0.2 S$ per eent.; degenerates, ì.1 per eent.

Urine: Negative, chemieally; no purasites seen.

Gastmic Exisuritios: Test meals. August 19, shredeled whent biscuit meal removerl after fortri-five minutes. Light yellow; gastric orlor, particles well brokeu up; 6.j e.c. recovered; la vage elear after 2 liters of water.

Clemieal examination: 'lotal acidity, 40; frec Ilel., 30; Uffelmann itud organie aeid ubsent.

Mieroscupic cxumination: Niunerons very active, flagellate protozon, the majority with "gromud-glass" appeuriug bodies; a few shggishly moving and darker. In warm preparations, four anterior flugellie discernible; undulating membriuse seen witlı diffienlty: 'Tluc organism was recoguized ns trichomonns hominis inul demonstrated ats such to several collengues. Many motile and non-motile baeilli. Faw ment fibers well broken up; starel, erythrolextrilı.

P'epsin nul remin redneed. Oecolt bloot-uegative (gutaine and old turpentine method). 
Angust 20. Slirelded wheat biseuit meal; removed sixty'-seven minutes after eating; 73 e.c. recorered; lavage elear af ter 3 liters of water. Extrict, lighit yellow, gastric odor; test foot well broken up.

Clemieal cxamination: Total aeidity, 45 ; free Hcl., 20; Uffelmam, Pettiukofer's, organic acids, nnd occult blood nbsent.

Microscopic examination: Few short non-motile rorls; no flagellate protozoa or amebre seen; slight mieroseopie fool retention. - l'epsin nnd remin present but reduced.

Angust 21. Slirelded whent biseuit meal removed thirty-five minutes after enting; 40 c.c. recoterel; light yellow, gastric odor; muens in slight excess. Lavage and test-menl flud, warm nornal saline solution.

Chemical exnmination: Total aeidity, 1S; free Hel, 6 (doulbtless not nceurate on account of nornml salt leeing administerel with test food). Uffelmann, Pettiukof(r, organie aeil, and occult blond absent.

Microseopic examination: Fnormons number of very actively' motile trielonionals sectl. Many dying nud deal forms, some coarsely grautlar and some vacuolatey. In some, when the prepalration was diluted with warm saline solution, mululnting membrancs well discermible. The trichomomads appear sinaller than those seen in this patient's stool (see below) but nre quite ns motile. As nearly ns conld be estimated the avernge length of the body was about 12 microus. No mensurements of the tails were unade. Specimens were kept on the warm stage the greater part of the morning, and with the frequent adlition of warm saline solution, actively motile forms were preserverl. Coll, or wirm, neil and alkaline solutions mpirly killed the fiagellates (lyydrochloric acid nbove $\mathbf{0 . 3}$ per cent.; neetic aeid, nitric neid; cunstie sodn, ciustic potasl, 1 per celit. lactic neid, 0.5 per cent. salieylie acil, and 1 per cent. carbolic acil solutions were usel). When the gustric extraets were diluted with aniline dye preparations (metlyylene blue, Graul's mixture, gentinn violet, Wriglit's stuin) in nn attempt to stnin the organisms, the smears sliowed small, contraeted, searcely recognizable dead organisms. Tubes of blood serum and glucose agar inoceulated witlı 5 drops of gastrie extraet, in which aetively motile trielıomonads were present in large numbers, revealed not even recognizalle dead organisms the following day, although there was an abundant grouth of baeilli. In the gastrie extraet itself incubated in three volumes of normal saline solution, no trieliomonals could be made out after twenty-four lours.

August 22. Fisting stomach; patient tubed at 5.25 A.s1. No contents obtained. Lavage witl warm normal saline solution was elear with the exception of small amounts of mueus. In the examination of seven specimens of tle lavage wnter nnd bits of mucus, only one trichomonad was seen. This was found in a bit of dense mueus and was not motile, even though the preparatious liad been kept warm since they were secured. 
August 22. Miegel dimter removed at 4.45 p.ar., 160 e.e. recovered. Lavige elear after 4 liters of warm saline solution. Extraet showed, maeroseopieally, mueh poorly eliewed food.

Chemical examination: 'Total aeidity, 16; free IId, 8; Uffelmann, Pettinkofer, organic absent; ocenlt blood, faint positive (guaiac and oll turpentine method).

Mieroscopic examination: Several small, grnnular, sluggishly motile triehomonads seen; flagelle very difieult to observe, even witlı subdued light. Many- long slenler, non-motile baeilli, usually in pairs. Food debris in various stages of digestion; mueus in excess.

Exasisatioss of Stools. Angust 22. Iarge, greenish-brown stool following 1 ounce of clontestic Carlsbad salts. Stool has peenliar foul, penetrating, Innsty odlor. Minch partly altered food and inueus, in tenacious strings and flakes. Reactionalkaline to litmus.

Chemical examination: Skatol, positive. Occult blood, faintly positive.

Mfieroscopic crannination: Euurmous umubers of large (15 to 22 mierons approximately) actively motile trichomounds; no ameba; grent numbers of loug sleuler inotile and non-motile baeilli; nucls food debris, poorly digested; inueus in excess.

Pnogkrss of TuE Case. 'Tlie following trentment wis suggested: Ifyclrargyri ehloridum mite, graiıs $r$, in dividled doses at bed time, followed by 1 ounec of salts before breakfast the following morning. This mediention was given twice weekly, and the stools were saved after ench bowel movement. Aeidum hydrochlorienm dilutum was given in doses of xux drops a lialf hour after meals, nnd repented an hour and a lialf after eneh neal. Gastric lavage on empty stomaeh, with large quautitits of 1 per cent. sodium salieylate solution was carried out thrce tinies weckly. Intestinal diet and boiled wnter were orlered.

After the pratient had lind two "rounds" of ealonel and salts, and several lavinges of salieylate of soda, triehomonads were no longer present in either gastric contents or stuols. Flatulence, llausen, lieadiehes, and weakness disilypeared. The patient felt so well that in late September a trip to Canada was allowel. On Oetober 3, she ugain reported saying that she felt well, although she had not been under trentment while away from Anu Arbor. A specinen of gastrie contents slowed no flagellate protozon. A fresh stool examined after Carlsbad salts had been administered showed enormous numbers of motile baeilli, mueh mueus and many triple pliospl late erystals. Examination of four fresh preparations on the warm stage revealed one large, very aetively motile trichomonad.

On Oetober 6 the patient was given $\mathbf{5 0}$ grains of thymol, in two doses, at bedtime, combined with 2 grains of calomel. At 7 A.s. 
the following morining an omuce of Carlsloul salts was nolministered. 'l'he stool was foul smelling, and contained unnel poorly digested food, lunt few motile bacilli and no trichomonats were seen.

The patient went Sontl on Oetober 10, feeling very well. Iler physicinu (Dr. Menj. Beeler, Alineral Wells, 'l'exas), was alvised regarding the condition present, and with his aid trentment was earried out along the above lines. The last time information was received from the patient (Spring, 1910), sle wus in excellent lealth, had gainerl weight, and had had no fintler return of protozoa in cither gastrie extmets or stools.

CAsE II.-Mrs. J., aged forty-seven years, uative of Mlichigan; referred by Dr. F. N. Bigclow; IIolly; Aliethigan, April 20, 1909 .

Subjectire Symptoms. Fecling of weight high in epigastrium, immediately" after enting, "sourness" of stomach, with bitter eruetations, flatulence; obstinate constipation; very annoving cough; facial neuralgian; pal pitation of leart; nervonsuess.

Fumily IIistory. Sister died of pulmonary tuberculosis; otherwise negative.

Personal Ilistory. Gool henltl until four yenrs since. Never pregullant.

Prescnt Trouble. About four years ano laul stomach disturbanees, which were diagnosticated "dilatition anul fermentation;" sulfered from clironic constipatiou and lecnorrhoids; lial a Whitehead operation performed for the hemorrhoids, and at that time lost a great deal of hlood, with resultant weakness. After opleration; stomach troulhle appeared to inuprove. 'lhe patient spent the last threc vinters in Forila.

In the fall of loos had hronchopnennomia; cousaleseel in Florila; improvel slowly; developer " whooping congll," which was so serere that vomiting frequently oecurrel, especially at night. Ilas been losing appetite, strength, ans weight during the list six montlıs. Ieccontly dereloped distressing sense of weight . ligh in the epignstrium, most morked immerlintcly after eating. with aeil crnetations and regurgitation of but slightly altered food; charieter of fool makes little differenee in this respeet; the eruetations frequently last for two hours after meals, and ure worse when lying down; voniting relieves. Of late constipation las become very olstinate, requiring strong catliarties. Wheul comstipaterl, neurnlgia and nervonsuess are agaravaded.

Examination. 'l'uperature, 99; respiration, 36; pulse, 92 (4 r.M.).

A moderately large, thick-set woman of asthunatic type; appreeiable cyanosis of tip of nuse, ears, and of lips; conglss frequently, and paroxysmally, congl having a slight "brassy" ring; selerotics slighlitly injected.

'Tongue heavily eonterl; throat-" "ninrked enlargenent, of true menrysmal type of the aseending pliaryngeal artery, from the 
level of the laryux to just nbove the nrifice of the Eustachian tube; the ressel shows marked pulsation thronghout the entire field of observation" (report of Professor R. Bishop Canfield).

Neek: Marked earoticl pulsation on right; no traclical tng, or positive venous pulsation.

Thorax: -Diffuse bronchitis, more marked in left lower back; moderate eardine hypertroplyy. Blood pressure: Systolie, 1.55; cliastolic, $10 \pm$ (Riva-Jlocci, $12 \mathrm{en}$. cutfi).

Ablomen: Distended and tympanitie; gurgling sounds throughout; stomach by inflation exteuls two fingers' breadth below the navel in the midline; tenderness high in the epigastrium and over the gall-bladder.

Radiogram: Moderate eardiac hypertroply; great vessels negative; pulmonary edeina; "dilated esoplingus" (Dr. V. J. villy).

Urinc: Trace of nlbumin in twenty-four-hour sample (acetic and ferricyanide test).

Sputum: "Curshmamn's spirals;" few alveolar cells containing blood pigment.

Blood: Red blood corpuscles, $4,360,000$; white blood corpuscles, 5240; lemoglobin, 90 per ecut. Differentinl formuln-(516 white cells counted). Small lymploeytes, 9.7 per cent.; large lympliocytes; 3.1 per cent.; transitionals, 6.4 per cent.; polymoplonueleur neutrophiles, 60.5 per cent.; esinophile polymoplionuelears, 2.4 per cent.; myeloeytes, 0.5 per cent.; degenerates, 10.8 per eent. No atypical red cells.

Gastme Exanisatios: April 2S. Test meal: Shrelded wheat biseuit and distilled wnter; removed serenty minntes after eating. Stomach tnbe passed with difficulty on account of enlargeel vessel in throat; paticut vomited $\mathrm{SO}$ e.c. of partly ultered test-Ineal food ehicfly before tube passed into stomacli; 40 c.c. of a cintry-yellow fluid removerl through tube; the latter containel an exeess of muteus, together with well-broken up food, and had a very sour odor.

"Vomitus:" Straw colored, slightly sour oulor; shredded whent biseuit poorly broken up; Congo and Gunzberg test faintly positive. Chemical examination: Total acidity, 4 ; free II blool, organic acirl, nnd Pettinkofer absent.

Mieroseopic examination: Poorly digested shredded wheat biseuit; one sluggishly moving, flagellate protozoon, with grammlar endoplasm; many motile bacilli.

Gastric Extract. Chemieal examination: Total acidity, 50; free H(l, 1S; Lffelinann, Pettinkofer, ocenlt blood (guaiac and . peroxide of hyd(rogen test) and orgnnie aeid nbsent.

Mieroscopic examination: Many rather small (average about S mierons) graunlar appearing, sluggislly motile trieliomonals; many globular, vicuolated, and contracted forms, apparently 
dead; many lenkoejtes and cell nuclci; enormous numbers of actively motile, long, and slender baeilli; food partieles, potato starch, shredded wheat bisenit fibers, few meat fibers well preserved, mneus in marked excess.

Digeslion. Pepsin and rennin present but grently diminished.

May 1. Fasting stomael; patient tubed at 9.15 A.s.., 45 c.c. canary-yellow fluid removed, mixed with slaggy strips of mueus, bits of hard egg und toast; lavage with warm normal saline solution, elear after ubout 3 liters. Some of the first coutents recovered, appeared to come from the esophagus, and were Congo negative.

Clremical exanination: Total aeidity, 22; free Hel, 14; Uffelmann, oecult blood, and organic-aeid tests negative. Pettinkofer, faintly positive. P'epsin and rennin-trace.

Mieroscopic examination: Few slightly motile, darkly granular trichomonads; many ovoid, balloon-shaped, and globular forms, exhibiting coarse endoplasm, frequently witl large vacuoles; many sliort non-motile bacilli, single and in chains of from four to six; cell nuclei inereased; muelı mueus, and mieroscopic food retention. This patient was not given a Riegel diuner at this time, on aecount of the dauger of tubing duse to the uneurysm of tlic ascending plaryngeal artery.

Stool Exasısitioss. April 29. Fresh specimen seeured after administration of 1 ounce of domestic Carlsbad salts on empty stomach. Large, greenish yellow, foumy, semi-lluid stool, with penetratiag, aerid, and musty odor; large strings of mueus, mixed with small particles of food remains.

Cliemical examination: Indol and skatol, positive; oceult blood, positive (guaiac und peroxide of lydrogen test).

Microscopic cxumination: Enormous numbers of very actively. motile, generally pyriform trichomouals. The majority hail fiucly granular bodies, and were unifornly larger than those seen in the gastrie extracts of the day previous and subsequently. Some were very large, measusing from 20 to $2 S$ mierons. With subdued light, and when the protozon were dying or entanglel in mueus or food debris, four anterior llagelle and the undulating membranes could be made out. On the warm stages, speeimens were kept the greater part of a Iorenoon, before they beeame sluggishly motile, coarsely granular, contracted or large and vaeuolated, preceding their death. Attempts were made to obtain stains by the carmine and the osmic acid-IVright-stain methods (as claborated by Freund under Professor Dock's direction at the University Hospital, AnII Arbor), but with no suecess. The cell bodies appeared to become disintegrated in tbe drying and fixing, so that only poorly stained debris showed. Probably greater experience with threse methods would have led to more satisfactory results. Attempts at eulture in the following media were made: (I) IIuman blood mixed with mueus from feces which had been 
previously washed in warm normal saline solution; (2) bouillon mised with blood serum; (3) normal saline solution alone; (4) 0.5 per cent. laetic aeid; 5 per cent. blood serum in normal saline solution; (5) solutions of 5 per cent. and of 10 per cent. $0 x$ bile in sodium citrate in normnl saline solution; (6) ox bile alone; $(7)$ 5 per cent. $0 x$ bile, nnd 5 per cent. blood sernm, with 0.5 per cent. laetic aeid in normal saline solution; (S) 5 per cent. ox bile, 5 per eent. blood serum in beef bouillon; (9) nlkaline saliva. All methods were unsuecessful. Cold water or salt solution, or these above $110^{\circ} \mathrm{F}$., rapilly crused dcath of the tricliomonads. Solutions of organic and inorganic acids (markedly acirl to litmus) and of alkalies (markedly alkaline to litmus) caused rapid disintegration of the parasites.

In the stool, in addition to the flagellntes were vast numbers of actively motile bacilli. There was much poorly digested food and mucus.

May 1. Stool passed without cathartic. Medium size, in flat ribbons, soft, eonted witls mucus; of penetrating musty odlor.

Cliemical cramination: Occult blool, and inclol negatire. Sclımidt's biclloride test, bilirubin.

Microscopic examination: No trichomonals in either liquid parts of stool or in bits of mueus, nlthough nine specimens were exnmined carefully; many motilc baeilli; muel poorly digested food.

Treatuent. This case was ticated similarly to Case I, with the cxception of frequent lavages. A preliminary lavage with 1 per cent. solution of sodium salieylate was given; after that "rounds" of calomel nnd salts, with doses of liydrochloric aeid after mcals. Frequeut small fecdings mitl intestinal dict relievel the epigastric distress, the regurgitations, and the flatulence. A sedntive controlled the conghing by lessening the nrterial pulsations that constantly tuggel at the larynx.

On June 3, the patient felt very well, had no gastric or intestiual protozon and returned home. She was seen again, with Dr. Bigelow, in the Fall of 1910. Exposure while on a cauping trip lad brouglit on cough and some return of old symptoms in the stomach. The esophagus and gastric extracts showed no tlagellate protozoa. The stools exhibited many sluggishly motile trichomonads, numerous motile bacilli, nnd an excess of mucus.

The patient was given a preliminary treatment of calomel and salts aud when the intestinal tract was well emptied had 60 grains of thymol administered in two doses at bedtime. This was followed by a saline cathartic the following morning. The stool showed no flagellate protozon, and ferr motile bacilli. The patieut returned home under treatment and las not becn lieard of since. 
II.

Inasmuch as the above cuses liave been ensidered in detail, elinically, hut little further comnient appears neccssary. Ifowerer, it wruld seem proper to briefly comphasize eertiin-facts.

Botl patients were women who had resided in semi-tropieal elimites; botl liad been reakened by illiess and loss of blool incident to surgical procelures; both patients haul liabitually partaken of unboiled water from surface wells and had donbtless nlso eaten freely of fresl, moist, green vegetables and fruit in all probability eontaminated. Neither patient had cxperienced periodie or clironic diarrhea; on tle contrary, obstinate constipation wis present in spite of the existence of enormous numbers of fligcllite protozon and motile and non-motile biseterial in the intestinal trict. This is somewliat musual where trieliomonads are present, but the condition lias also been observed by Freund (Case VII, his series) and others. In each ense, gastro-intestinal symptoms were prominent. These were nausea, flatulence, nbdominal distention, eolicky paius, and constipution. . Skatol and indol were present in the stools and so-called "intoxiention symptoms," as hendaclies, neuralgia, and exlunustion were observed. "The blood slowed slight anemia, witlı inerease in cosinopliiles and degeneraterl lcukncytes.

The test meal revealed microseopic sctention-lowercd total and free hydrochlorie acid (sliredderl wheat biseuit meal) as well as increasel amount of mueus containing great numbers of bietcria and triehomounds. The stools were the cliarieteristic greenishbrown, semi-liquil variety of protozoan infection after Carlsbad salts hive been adıninistered. Bits of mueus, occasional nltered blood, rich flora; aud partly digested food were conconitent with the linge numbers of trichomonas hominis.

In these patients one can only surmise the souree of the infertion of the esophagus, stomach, and intestines by the fugellates. It nuy be that the finding of the protozon in the esophangus and stomael was secondary to a primary foeus in the duodenum and jejumm, tlic organisıns passing upward throngh insuffieient splineter pylori. It seems probable nlso that the trichomonads were ingestel witl food and water. Some of them, proteeted by mueus in the lorrer esophagus and in the stomach may not have been immediately killed by the neid gastrie secretion.

Food and warter mily be contaminatel readily in a great many ways. Fligellates may exist in the sputun of patients with tonsillar or uasal abseess (Lcuckliart ${ }^{17}$ ) or in sputum from non-tubereulous lung carvities, for example, bronchiectasis (Litten, ${ }^{19}$ Lenlartz ${ }^{19}$ ),

14 1xe. rit,

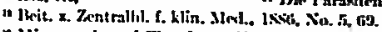

* Mirruscopic und Clicuie an linakenk-tle, p. 61 (Dork). 
or where individuals are affected with markedly carious tecth (v. Leyden,"0 Prowazek,"1 Theobald=), or oral cancer (Cohnheim). Dock ${ }^{3}$ has mentioned the finding of trichomonads in the diseliarges of snails, frogs, and ducks. The stools of patients afiected with typhoid fever, amebie dysentery, cholera or enteritis, primary or sccondary to malignant disease of the stomach or bowel, may be rich in trichomonads (Dock,"1 v. Jaksch, 25 Epstcin, $;$ Davaine, ${ }^{27}$ Grassi,"s MIny,"3 ct al.). Hunt ${ }^{30}$ las reported thic finding of flagellates in perincal abscess, Cunningham" noted their presence in a case of absecss of the liver. As Doek: has obscrved, the presence of trichomonads in urinc may be rcsponsible for wide disscmination. The possibility of resistant spore forms of the flagellates explains thicir viability under adversc conditions.

Morphologically, the parasite scen in the 2 eases here reported differs very little from the elassic picture of triehomonas hominis as established by Donnew3 and Dock.at Inasmuch as the protozoa deseribed by these and other observers and ourselves showed four anterior flagella together with an undulating membrane, it rould seem that the "new" form of triebomonas recently described by Aleriefis conforms only to type. It might be observed that the trichomonads seen in the gastric extracts in our cases were approximately but half so large as those found in the stools of the same host. They secmed less resistant to external influences, but in other respeets resembled the larger variety:

The eases presented contribute no facts regarding the much debated question of trichomonas hominis as an etiological factor. Certainly its removal in quantity from the gastro-intestinal tract of its host is attended by elinical benefit. It has been advanced frequently that the presence of great numbers of flagellates aets as a mechanical irritant to the intestinal mucosa or that such protozon secrete a substance which is irritant. While these observatious may be true, wc feel that other factors miglit be considered.

Thic rapid multiplication of intestinal bacteria and protozoa (as triclomonads) results in a grcet quantity of protcin-containing flora in all stages of viability. In the life cycle of the trichomonas dead forms necessarily result. What action succus entericus or associated bacteria and the like lave toward hastening this death we arc not prepared to statc. The dead forms impose upon the digestive juices an excess of protcin ("forcign protcid") for clcavage

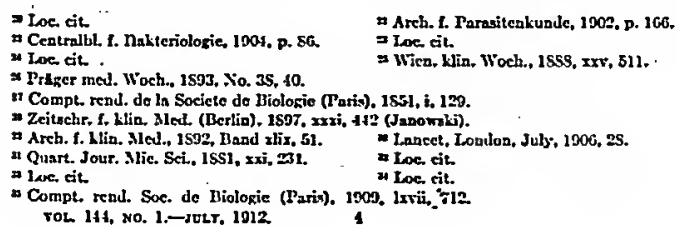


As the work of Vaugham ${ }^{ \pm 5}$ and his associates has shown, this protozoic protein ean be consilered homologous to any other protein, chemically: The hydrolization (elenvage) of this protein by digestive ferments or associated bacterial enzymes, results in the production of so-called "toxie" and "non-toxie" groups. These may be further split to nmino acids or simpler radieles. It is suggested, in view of these faets, that these eleavage products of the protein contained in the flagellates may be a not inconsiderable influcnee either as (1) a gastro-intestimal irritant; (2) a factor in altering metabolie change in digestive glands; (3) a souree of so-called "intoxieation symptoms" elinically.

\section{SACRO-IIIAC DISPLACEMENT.}

\section{Br Jasies K. YouxG, MI.D.,}

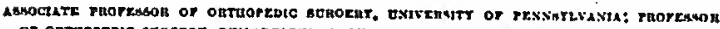

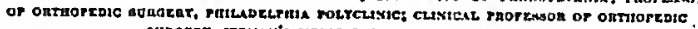

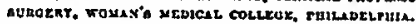

Is order to facilitate a study of saero-iliae displicements, and to arrive at a clearcr understanding of the parts involved, it becomes necessary to review the nuatomical peculiurities of that articulation, as well as the mcelianism of the pelvis, with its correlated structures, in so far as they relate to the subject abont to be discussed.

Asatoms. The sacro-iline articulation partakes both of the nature of a true aud a lialf joint. It possesses a hyaline articulis cartilage, a synovial membrane, and n capsnlc, ant it derives its strength and toughness fron its anatomical position is well as from its powerful ligamentous attachments.

This pelvie joint which is formel by the opposed cartilagecovered surfaces of the saerum and ilium, separated by a symovial eavity endosed in the saero-iline ligament, is well fortified by many layers of strong ligamentous fibers, thnt not only fill the interval between the two contiguous bones, bit nre firmly nttiched to the rough iline aren belind its nrtienlar surfice and which extend to the back of the lateral masses of the salerum.

This posterior sacro-iliae ligament is far more inportant than the oblique sacro-iliae, which passes from the posterior superior iliac spine to the second and third sieral vertebre. The iliolumbar lignment, a triangular baud of strong fibers, nud the saerolumbar ligament, a bundle of direrging fibers, likewise contribute

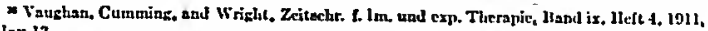
Siny 13 . 